Impact of trimethoprim on the river microbiome and antimicrobial resistance.

2

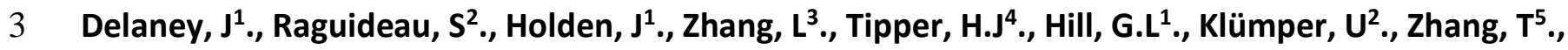

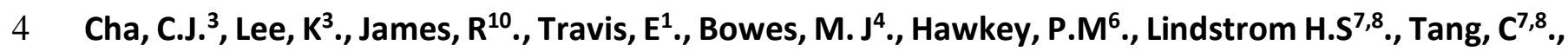

5 Gaze, W. $\mathrm{H}^{3^{*}}$., Mead, $A^{9^{*}}$., Quince, $C^{10^{*}}$., Singer, $A^{4^{*}}$,, Wellington, E.M. $H^{1^{*}}$.

6

$7 \quad{ }^{1}$ School of Life Sciences, University of Warwick, Coventry, UK

$8 \quad{ }^{2}$ Warwick Medical School (WMS), University of Warwick, Coventry, UK.

$9{ }^{3}$ European Centre for Environment and Human Health, University of Exeter Medical School, ESI,

10 Penryn Campus, Cornwall, UK

114 UK Centre for Ecology and Hydrology, Wallingford, UK.

$12{ }^{5}$ Department of Civil Engineering, The University of Hong Kong, Hong Kong, SAR, China.

13 Institute of Microbiology and Infection, University of Birmingham, Edgbaston, UK.

$14 \quad{ }^{7}$ Department of Chemistry, Umeå University, 90187 Umeå, Sweden.

${ }^{8}$ Department of Public Health and Clinical Medicine, Occupational and Environmental Medicine, Umeå

University, 90187 Umeå, Sweden.

${ }^{9}$ Applied Statistics Group, Department of Computational and Systems Biology, Rothamsted

18 Research, Hertfordshire, UK.

${ }^{10}$ Earlham Institute, Norwich Research Park, Norfolk, UK.

\title{
Introduction
}

23 Antimicrobial resistance (AMR) is a global health issue, with forecasts predicting ten million deaths a

24 year by 2050 if resistance levels continue to rise (O'Neill and The Review on Antimicrobial Resistance, 
Palme et al, 2018). However, the environment is now being acknowledged as a substantial contributor

to the global spread of antibiotic resistance (Wellington et al, 2013 \& Singer et al, 2016;2019). Rivers

and waterways are prominent examples of environmental settings that have been identified as a

major repository and route for dissemination of both low levels of antibiotics and antibiotic resistance

genes (ARGs) (Pärnänen et al, 2019; Amos et al, 2015).

A recent study quantified antibiotic concentrations in freshwater samples taken at a range of sites located on the Thames river catchment; the highest levels of antibiotics (as well as many other drugs) were recorded downstream of waste-water treatment plants (WWTPs) (Holden et al, 2020). While the origin and fate of these antibiotics could be strongly linked to community and clinical use, the impact that they have on the emergence of antimicrobial resistance in the environment remains unclear (Aslam et al, 2018). It has been proposed that ARGs have emerged within environmental bacteria to provide a protective effect against these polluting drugs (Märtinez et al, 2012). This is of concern to human health, as the genes under selection may be clinically relevant and have the potential to be transferred between environmental and clinical bacteria via horizontal gene transfer (HGT) (Baquero et al, 2008). However, it is also widely recognised that the evolutionary arms race, or red queen hypothesis: the concept that species need to continually adapt, evolve, and proliferate to survive plays an important role in shaping the environmental resistome (Papot et al, 2017). The fact that ARGs have continually emerged within the riverine environment to protect against antibiotic producing organisms in the riverine environment supports this latter concept (Singer et al, 2016). As a result, the primary drivers of AMR within complex riverine bacterial communities remain difficult to define.

We have previously shown that the prevalence of an integron borne ARG, sul1, correlates with the concentration of several antibiotics across river sites on the Thames catchment (Holden et al, 2020). sul1 provides resistance to sulfonamides, a bacteriostatic class of antibiotics that were originally 
synthesised in the 1930s. Sulfonamides bind to dihydropteroate synthase (DHPS) in bacteria and

hinder dihydrofolic acid formation which is vital for vitamin B formation and bacterial growth (Sköld, 2000). One sulfonamide; sulfamethoxazole (SMX) can be prescribed with trimethoprim (TMP) as co-

trimoxazole to treat chronic bronchitis, shigellosis, and Pneumocystis carinii pneumonitis (Alsaad et pathway, allowing co-trimoxazole to be effective against most aerobic gram-negative and grampositive organisms (Macejko and Schaeffer, 2008) (Figure 1).

A)

64

65

66

67

Figure 1- A) Chemical structure of SMX/TMP<smiles>COc1cc(Cc2cnc(N)nc2N)cc(OC)c1OC</smiles>

B) dihydropteroate diphos phate + p-aminobenzoic acid (PABA)

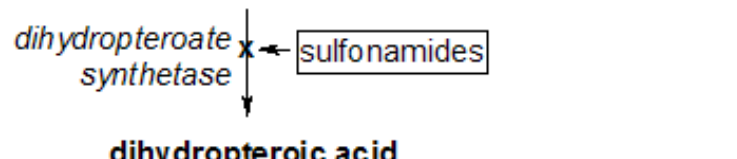
dihydropteroic acid<smiles>Cc1cc(NS(=O)(=O)c2ccc(N)cc2)no1</smiles>

dihydrofolic acid

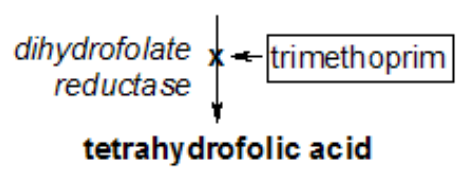

B) SMX and TMP combined mechanism of action

Despite the synergistic effects of SMX and TMP, recent human antibiotic prescription surveillance data suggests that TMP is more commonly prescribed as a single-dose antibiotic for clinical purposes (Ashiru-Oredope et al, 2014). Furthermore, the recent veterinary medicines directorates report on antibiotics showed that a combined volume of $66.2 \mathrm{mg} / \mathrm{kg}$ of sulfonamides/TMP was used to treat infections in pigs in 2015, which accounted for the highest proportion of all antibiotics prescribed for pigs (24\%) (Bos et al, 2019). Studies have identified several different ARGs relevant to TMP (DfrA1, $D f r E, D f r B 2 / 3, D f r B 1 / 6)$ (Šeputienè et al, 2010) and sulfonamides (sul1, sul2, sul3, sul4) (Razavi et al, 
2017). Due to the prominence of sulfonamide resistance in the environment, the sul1 gene has

become incorporated into the structure of many class 1 integrons (CL1s) ( $\mathrm{Na}$ et al, 2014). Several studies have noted the persistence of sulfonamide and TMP resistance genes in the same environmental settings, often located on the same plasmids (Phuong Hoa et al, 2008; Kiiru et al, 2013; Muziasari et al, 2014).

During our previous work, sites on the Thames catchment with elevated TMP levels were identified (Holden et al, 2020). Despite this, there is still no evidence for a causative relationship between the residue of antibiotics such as TMP and the prevalence of ARGs (Holden et al, 2020). It is possible that the correspondence between ARGs and drugs downstream of WWTPs is purely correlative, as both are being released from the treatment process at the same time. In fact, studies have suggested that WWTPs themselves, as opposed to river sites are 'hotspots' of ARGs and therefore most of the selection for resistance occurs before antibiotic residue enters the riverine environment (Lood et al, 2017; Pazda et al, 2019; Fouz et al, 2020).

The aim of the current study was to analyse a combination of large metagenomic, geospatial and chemical datasets, to compare twenty sites across the Thames river catchment. Specifically, we aimed to look at sites with the highest and lowest TMP levels and establish the role that factors such as proximity to WWTPs, population equivalence $(\mathrm{PE})$ and land coverage play in the accumulation of TMP at river sites. A secondary aim was to investigate seasonal variation in the levels TMP and SMX at river sites. Lastly, as TMP can be prescribed alongside SMX as co-trimoxazole, we aimed to establish if the levels of TMP and SMX identified at these specific sites mirrored the prevalence of ARGs relevant to TMP (Dfr genes) and SMX (sul genes). 
104 A total of 69 sampling locations were chosen within the Thames catchment. However, metagenomic data was only generated for twenty of these 69 sites, and these twenty sites were analysed during

106 this study. All locations provide a depth of understanding regarding long-term water quality parameters. A subset of these locations also contributed to a previous effort on modelling AMR within the Thames Catchment (Amos et al 2015). The remaining sampling locations were selected to maximise the diversity of river environments, river inputs, and adjacent land uses. Specific sampling

110 locations within a river catchment were selected to capture upstream and downstream positions

111 from a known river discharge or confluence. All locations also had to consider site accessibility as a

112 factor. Key discharges and confluences which structured sampling location choice were wastewater

113 treatment plants, agricultural fields (e.g., animal grazing), urban runoff, canals, fish farms, and other 114 rivers (see Table 1 Figure 1).

In the specific case of WWTPs, small WWTP were plants serving a population less than 10,000 and

117 any plant serving over 10,000 was considered large. WWTP impact was determined based on size of

118 the nearest WWTP and distance from the plant. Impact was determined based on distance away

119 from the WWTP.

121 Table 1 Summary of the twenty sampling sites analysed in this study

\begin{tabular}{ccccc} 
Name of Site & $\begin{array}{c}\text { Thames } \\
\text { Tributary }\end{array}$ & $\begin{array}{c}\text { Nearest } \\
\text { upstream } \\
\text { Thames WWTP } \\
\text { and treatment } \\
\text { type (Secondary } \\
\text { (S) or Tertiary (T) }\end{array}$ & $\begin{array}{c}\text { XY } \\
\text { coordinates }\end{array}$ & Postcode \\
\hline 1. Coln1 & River Coln & Withington (S) & $\mathrm{X}: 410239$ & GL7 5NY \\
2. Coln2 & River Coln & Withington (S) & $\begin{array}{c}\mathrm{Y}: 207637 \\
\mathrm{X}: 411501\end{array}$ & GL7 5NW \\
& & & $\mathrm{Y}: 206777$ &
\end{tabular}




\begin{tabular}{|c|c|c|c|c|}
\hline 3. Coln3 & River Coln & Bibury (S) & $\begin{array}{l}X: 414943 \\
Y: 201324\end{array}$ & GL7 4AF \\
\hline & River Coln & Fairford (S) & $X: 416285$ & GL7 4LX \\
\hline 4. Coln4 & & & $Y: 200409$ & \\
\hline & River Cut & N/A & $x: 488447$ & BG42 6JQ \\
\hline 5. Cut1 & & & Y:171940 & \\
\hline & River Cut & Ascot $(S)$ & $x: 485223$ & RG42 5NR \\
\hline 6. Cut2 & & & $Y: 171833$ & \\
\hline & River Cut & Bracknell $(T)$ & $x: 485544$ & RG42 \\
\hline 7. Cut4 & & & Y:173282 & \\
\hline 8. Cut6 & River Cut & Maidenhead (T) & $\begin{array}{l}X: 490245 \\
Y: 179218\end{array}$ & SL6 2AR \\
\hline 9. Leach1 & River Leach & Northleach (S) & $\begin{array}{l}X: 420266 \\
Y: 204232\end{array}$ & GL7 3NS \\
\hline 10. Leach2 & River Leach & Lechlade (S) & $\begin{array}{l}X: 422552 \\
Y: 199090\end{array}$ & GL7 3HA \\
\hline 11. Ray1 & $\begin{array}{c}\text { River Ray } \\
\text { (Thames } \\
\text { headwater) }\end{array}$ & N/A & $\begin{array}{l}X: 410831 \\
Y: 187351\end{array}$ & N/A \\
\hline 12. Ray3 & River Ray & N/A & $\begin{array}{l}X: 412867 \\
Y: 185375\end{array}$ & SN5 7UJ \\
\hline 13. Ray4 & River Ray & Swindon $(T)$ & $\begin{array}{l}X: 412403 \\
Y: 186741\end{array}$ & SN2 \\
\hline 14. Ray5 & River Ray & N/A & $\begin{array}{l}X: 412310 \\
Y: 187249\end{array}$ & SN2 \\
\hline 15. Ray6 & River Ray & Swindon $(T)$ & $\begin{array}{l}X: 411910 \\
Y: 192617\end{array}$ & SN6 6 \\
\hline RiverThames1 & $\begin{array}{c}\text { River } \\
\text { Thames }\end{array}$ & Castle Eaton (S) & $\begin{array}{l}X: 417451 \\
Y: 196098\end{array}$ & SN6 7RX \\
\hline RiverThames3 & $\begin{array}{c}\text { River } \\
\text { Thames }\end{array}$ & Witney $(T)$ & $\begin{array}{l}X: 444319 \\
Y: 208614\end{array}$ & OX29 4BT \\
\hline 18. Thame1 & $\begin{array}{l}\text { River } \\
\text { Thame }\end{array}$ & Rowsham (S) & $\begin{array}{l}X: 479984 \\
Y: 215448\end{array}$ & HP19 9UA \\
\hline 19. Thame2 & $\begin{array}{l}\text { River } \\
\text { Thame }\end{array}$ & Aylesbury (T) & $\begin{array}{l}X: 477886 \\
Y: 213623\end{array}$ & N/A \\
\hline 20. Thame7 & $\begin{array}{l}\text { River } \\
\text { Thame }\end{array}$ & Little Milton (S) & $\begin{array}{l}X: 460064 \\
Y: 197680\end{array}$ & OX10 7AW \\
\hline
\end{tabular}

126 Samples were collected on two- or three-day sampling campaigns in August 2015, early March 2016

127 and August 2016. Sampling was carried out using purpose-made expandable sampling poles to allow

128 access across the riverbed. The poles were fitted with a machined holder that secured a 50ml falcon

129 tube. Sediment samples were collected by extending the pole into the river and scraping the upper

130 sediment layer into the tube until it was largely full. Sediment tubes were stored on ice. Samples were 
collected at each site in triplicate. Water samples were collected in $500 \mathrm{ml}$ screw cap bottles and

132 stored on ice. Samples for nutrient analysis was prepared as previously described (Amos et al, 2015).

\section{Sample Processing}

136 DNA extraction was carried out using the FastDNA ${ }^{\mathrm{TM}}$ spin kit for soil following manufacturers protocol,

$1370.5 \mathrm{~g}$ of sediment (wet weight) was used. DNA was pooled after extraction in $75 \mu$ l to give total DNA 138 in final volume of $150 \mu \mathrm{l}$.

Metagenome

142 PCR free shotgun libraries were prepared for each sample from 2.5 ug metagenomic DNAs by Exeter

143 Sequencing Service for the metagenomic sequencing using the TruSeq DNA library Prep Kit

144 (Illumina). The libraries were sequenced to approximately 7GBp using the HiSeq 2500 rapid run 145 mode (2X 250 bp paired end) by the Exeter Sequencing Service (http://sequencing.exeter.ac.uk/). A repeat sequencing effort was done on six DNA samples to determine if the coverage was sufficient

147 and each library was sequenced to provide $35 \mathrm{GBp}$ per sample and the total was assembled as 148 below.

Metagenome assembly, annotation and coverage

152 Metagenome assembly was performed using megahit v1.1.3 with option -k--min 29 (Dinghua et al, 153 2015). Three assembly schemes were implemented, assemblies per sample, co-assemblies of samples 154 from the same tributary and a unique co-assembly built from all samples. Comparison of the 3 
500 nucleotides were discarded. Gene prediction was carried out using prodigal v2.6.3, with option -

157 p meta (Hyatt et al, 2015). A selection of 36 Single copy Core Genes (SCG) were annotated through

158 rpsblast v2.9.0 using pssm formatted COG database made available by the CDD (Tatusoy et al 2000;

159 Lu et al, 2020). Best hits were filtered so that hit span at least $50 \%$ of the query with an e-value smaller

160 than 1e-5. Additionally, ARG and int/1 annotation was completed using diamond v0.9.9 (Buchfink et

161 al, 2015). Databases for both were sourced from (Lee et al, 2020), clustered respectively from of CARD

162 (Jia et al, 2017) and NCBI sequence search. Best hits were filtered using $80 \%$ query coverage, $80 \%$

163 percentage identity and $20 \%$ subject coverage. Taxonomic annotation was carried out using diamond

164 blastp on a NR database reduced to prokaryotes (Pruitt et al, 2005).

165 Assembly was converted to contig graph using megahit toolkit, it was then translated to orf graph

166 using result from gene prediction in custom python script. Visualisation of annotations on orf graph is

167 done through bandage v0.8.1 (Wick et al, 2015).

168 Samples were mapped to contigs using bwa-mem v0.7.17-r1188 (Li, 2013). Contig and genes mean

169 coverage were computed through both samtools v1.5 (Li et al, 2009) and bedtools v2.28.0 (Quinlan

170 et al, 2013). Coverage of functional feature, such as SCG, AMR or int/1 were obtained by summation

171 of coverage of genes sharing the same annotation. All coverages are normalised by sample, using

172 the median of the 36 SCG coverages.

\section{Chemical Analysis}

176 For each site $100 \mathrm{~mL}$ of each water sample was acidified to $\mathrm{pH} 3$, internal standards were added and

177 the sample was extracted with a solid phase extraction (SPE) vacuum manifold system using Oasis HLB

178 (200mg) cartridges. Thereafter each sample was evaporated to $<10 \mu \mathrm{L}$, reconstituted to a final volume

179 of $0.1 \mathrm{~mL} 5 \%$ acetonitrile with $0.1 \%$ formic acid and $10 \mu \mathrm{L}$ of each water sample was analysed with 

analytical methods used to analyse most of the pharmaceuticals, and the validation of each method is shown in (Holden et al, 2020). However, at the time of sample analysis, contamination in the LCMS/MS system interfered with the analysis of the six biocides included in the study. Instead, an analytical method developed by (Östman et al, 2017) specifically for biocides, on the LC-MS/MS system, was used to analyse the six biocides.

\section{Geospatial analyses and meteorological data}

All geospatial analyses were performed using ArcGIS v10.4 software (ESRI, Aylesbury, UK). To analyse possible drivers of AMR for each sampling site, an upstream catchment of that location was delineated using the hydrology tools to create a flow accumulation and flow direction layer per site, and subsequently a watershed (upstream catchment), using a 50m grid interval hydrological digital terrain model (the Centre for Ecology and Hydrology Integrated Hydrological Digital Terrain Model (IHDTM)) (Morris \& Flavin, 1994). A Network Dataset was created from the Thames river data, using the needed for distance measurements, including WWTPs. Data on WWTPs was obtained from the environment agency (Environment Agency, 2012; Environment Agency, 2013). To analyse upstream land use, and more specifically to calculate the percentage land cover of each sample site watershed, the Centre for Ecology and Hydrology Land Cover Map 2015 (Rowland et al, 2017) and Land Cover Plus: Crops Map 2016 were used (NERC CEH, 2016).

Land-cover profiles were calculated for each sampling site based on the identified watershed, comprising the percentage cover for 13 broad habitat classes (Arable horticulture, Acid Grassland, 
horticulture" class was further sub-divided into 12 primary crop categories, and three further major

land-cover classes were also calculated by summing over broad habitats (All Grassland (sum of 5 broad habitats), All Woodland (sum of 2 broad habitats), Urban-Suburban (sum of 2 broad habitats)).

For each WWTP in each watershed, data on the Population Equivalent (overall sewage load), resident and non-resident populations and industry load (all in terms of the people producing the equivalent sewage load assuming 200 l of sewage flow containing $60 \mathrm{~g}$ of BOD per person per day) were tabulated together with the river distance $(\mathrm{m})$ from the WWTP to the sampling site, the dry weather flow at the WWTP ( $\mathrm{m}^{3}$ per day) and the general classification of sewage treatment plants (WWTP Type: SA -

215 Secondary Activated Sludge; SB - secondary biological filter; TA - Activated Sludge with tertiary treatment; TB - Biological filter with tertiary treatment). Simple summaries of these data were

217 calculated for each watershed (sampling site), including total numbers of WWTPs and number for each Type, mean, minimum and maximum distance, and mean and maximum PE. Based on the modelling approach developed in (Amos et al, 2015), summaries of the potential aggregated impact of upstream WWTPs were also calculated - these weighted the impact of the load (PE) from each WWTP by the inverse of the distance raised to a power $(0,0.35$ (close to the value estimated in the model fitting in (Amos et al, 2015), 0.5 or 1), allowing for different decay functions (with a power of zero indicating no impact of distance). Where (Amos et al, 2015) only considered WWTPs within a $10 \mathrm{~km}$ radius of the sampling site, summaries of the numbers of WWTPs and the inverse distanceupstream as well as for the whole upstream watershed. Data were also tabulated for each sampling 


\section{Statistical analysis and model development}

231

Initial analysis of chemical data used a mixed-effects model with Tukey's multiple comparison tests

to assess differences in trimethoprim (TMP) and sulfamethoxazole (SMX) concentrations between seasons (summer \& winter) and between twenty sample sites (Coln1, Coln2, Coln3, Coln4, Leach1,

Leach2, Key1, Ray1, Ray6, Ray4, Ray3, Thames1, Thames3, Thame7, Thame2, Cut1, Cut2, Cut4, Cut6,

236 Thames6).

Analysis of geospatial data relating to the distance (metres) of the twenty sample sites downstream

from waste-water treatment plants (WWTPs) and the concentration of TMP was carried out using

240 Spearman's rank correlation coefficient due to the non-parametric nature of the data. Both variables

241 were log-transformed prior to analysis. Analysis of the difference in population equivalence (PE)

242 between sites with the highest and lowest TMP levels was carried out using an unpaired t-test with

Welch's correction.

Analysis of metagenomic data used multiple t-tests with Bonferri-Dunn correction to assess differences in ARG (sul1, sul2, dfrB1/6, dfrB2/3,dfrE) and int/1 prevalence between seasons (summer and winter). Two-way ANOVA was also applied to assess differences in the prevalence of aforementioned ARGs \& int/1 between seasons and sites with the four highest (Cut4, Ray4, Cut6, Ray6) and four lowest (Coln1, Coln2, Coln3, Leach1) TMP concentrations. 

were taken from (Ordnance Survey, 2016).

\section{Results}

Analysis of TMP and SMX levels

The levels of TMP and SMX identified in the water at the twenty different sites across Thames

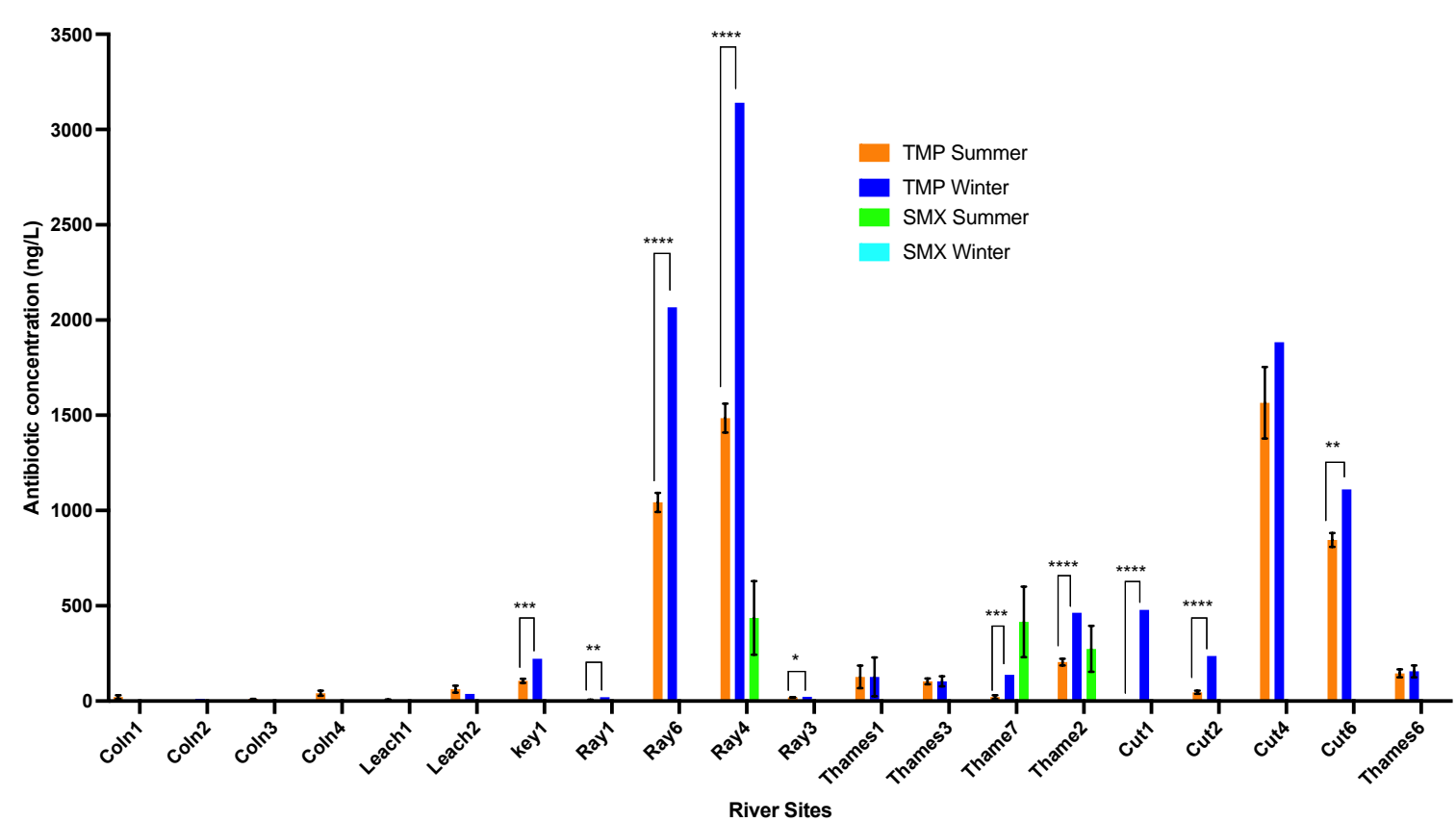

Figure 2- The concentrations of TMP and SMX at twenty sites across the Thames catchment in summer

$274(n=6)$ and winter $(n=3)(S E M)$. The sites were ordered by geographical location across the catchment, with Coln1 being furthest East and Thames6 being furthest West.

TMP concentrations were higher than SMX concentrations at all sites other than Thame7. Ten of the twenty sites had significantly higher TMP in winter compared to summer (mixed effects model). Four 

compared to summer for these sites (mixed effects model).

For three sites (Ray4, Thame7 and Thame2), the concentration of SMX was higher in summer compared to winter, but these differences were not significant (mixed effects model).

Figure 3- Relationship between distance of sample sites downstream from a WWTP and the concentration of TMP across 20 sites on the Thames catchment.

297 A significant negative correlation was observed between the distance of sites downstream from the nearest WWTP and the TMP concentration across 20 sites on the Thames catchment (Spearman $r=$ $0.456 \& p<0.05)$. This relationship was further explored to determine where the highest and lowest TMP levels were detected (Table 1).

Table 1- A sub-set of four sites that showed the highest and lowest TMP concentrations from the 20

303 sites. Of this sub-set, only one of the sites showed a recordable concentration of SMX (Ray4), so this 
306 *Secondary: 'Treatment methods include biological filtration (including conventional filtration,

307 rotating biological contactors and root zone treatment (where used as a secondary treatment stage),

308 alternating double filtration and high rate filtration'.

309 (Sewage Treatment in the UK, 2020).

310 *Tertiary: 'Works with a secondary activated sludge process whose treatment methods also include

311 rapid-gravity sand filters, moving bed filters, pressure filters, nutrient control using physico-chemical

312 and biological methods, disinfection, hard COD and colour removal, where used as a tertiary

313 treatment stage' (Sewage Treatment in the UK, 2020).

\begin{tabular}{|c|c|c|c|c|c|}
\hline River Site & $\begin{array}{c}\text { Nearest } \\
\text { upstream } \\
\text { WWTP }\end{array}$ & $\begin{array}{c}\text { Distance from } \\
\text { WWTP }(\mathrm{m})\end{array}$ & $\begin{array}{c}\text { WWTP Treatment } \\
\text { Type* }\end{array}$ & $\begin{array}{c}\text { Human } \\
\text { population } \\
\text { served }\end{array}$ & $\begin{array}{c}\text { Trimethoprim } \\
\text { concentration } \\
\text { (ng/L) }\end{array}$ \\
\hline Cut4 & Bracknell & 1361 & Tertiary & 90,000 & 1671 \\
\hline Cut6 & Maidenhead & 1540 & Tertiary & 87,400 & 934 \\
\hline Ray4 & Swindon & 1213 & Tertiary & 210,000 & 2037 \\
\hline Ray6 & Swindon & 10208 & Tertiary & 210,000 & 1384 \\
\hline Coln1 & Withington & 16677 & Secondary & 230 & 14 \\
\hline Coln2 & Withington & 18688 & Secondary & 230 & 4 \\
\hline Coln3 & Bibury & 9479 & Secondary & 600 & 5 \\
\hline Leach1 & Northleach & 20270 & Secondary & 1,670 & 4 \\
\hline
\end{tabular}

314

315 Three of the four sites with the highest TMP concentrations were located within 2000 metres of

316 WWTPs (Table 1) as expected from the data in Figure 4. The four sites with the highest TMP

317 concentrations were located closest to tertiary WWTPs, whereas the all of the four sites with the

318 lowest TMP concentrations were located closest to secondary WWTPs. Two of the four sites with the

319 highest TMP concentrations (Ray4 and Ray6) were located closest to the same Swindon WWTP. 
Land use and PE data were assembled for the four sites with the highest and lowest TMP

a) Thames Catchment

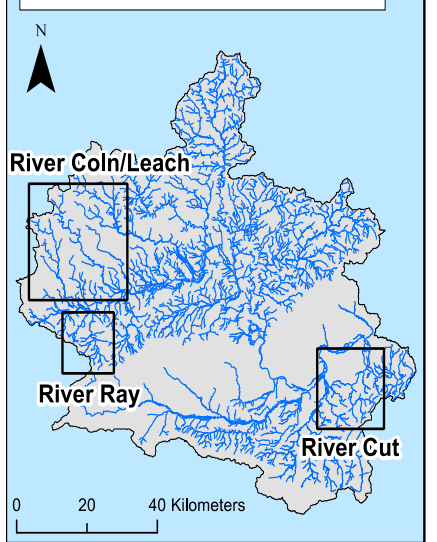

332

342 Examination of the land-use data in proximity to sites with highest and lowest TMP levels indicate

343 urbanization correlating with tertiary WWTPs and high TMP levels (Figure 4). The data also shows that

344 the proportion of arable and pasture-based land coverage was higher within the catchment of sites furthest from WWTPs.

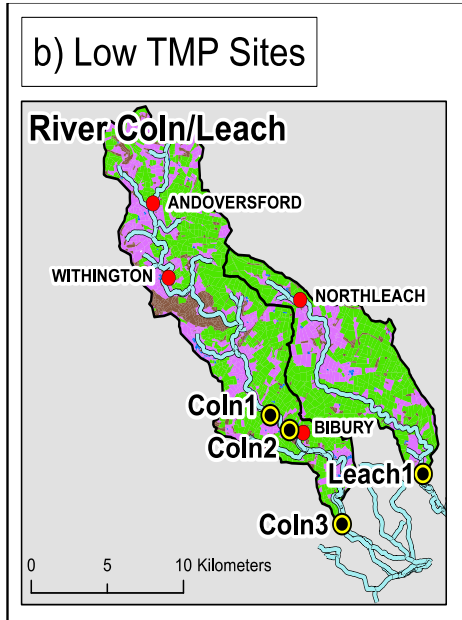

\section{c) High TMP Sites}
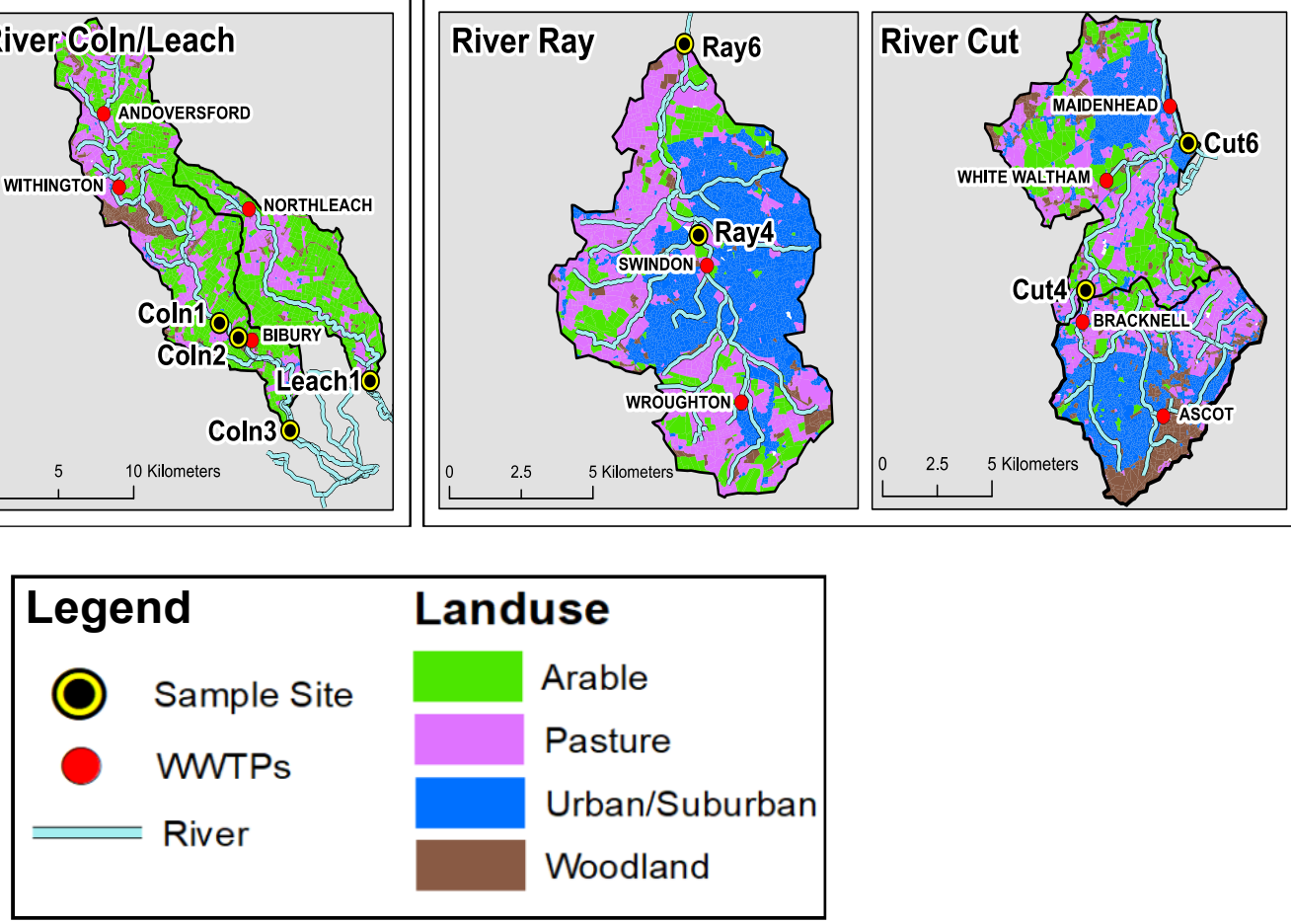

\section{Figure 4}

A) Locations of the Rivers Cut, Ray, Coln and Leach on the Thames catchment.

B) Locations and land-use corresponding to the four sites with the lowest TMP concentrations.

C) Locations and land-use corresponding to the four sites with the highest TMP concentrations. 


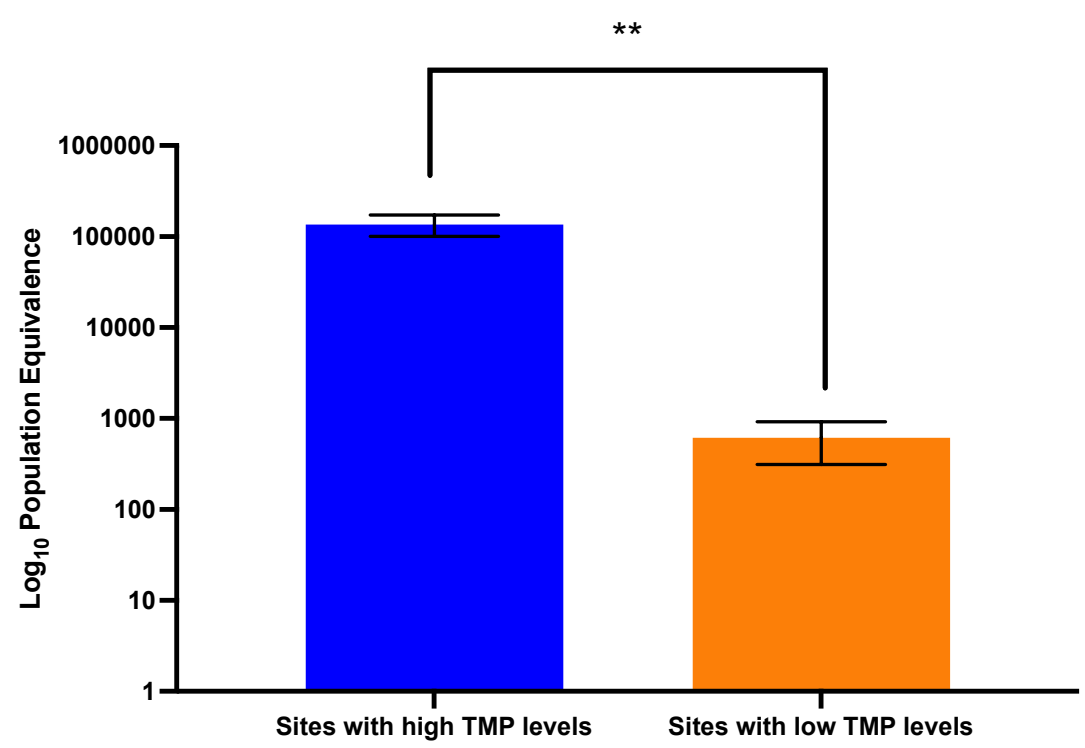

Figure 5- The average $\log _{10}$ population equivalence (PE) for four sites with the highest TMP the PE for the four sites with the lowest TMP concentrations (unpaired t-test).

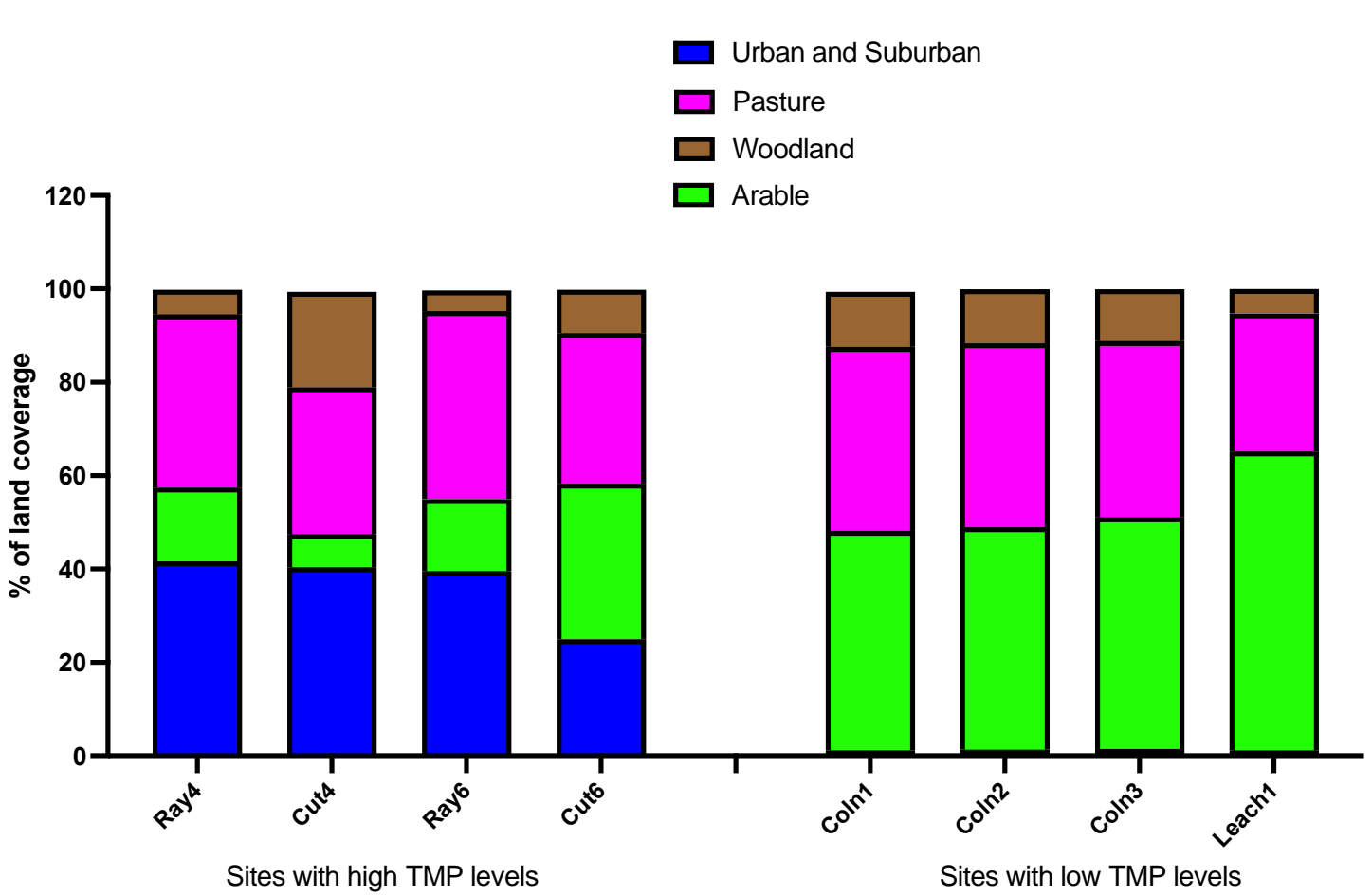


373 Figure 6- Percentage of land coverage within the catchment of four sites with the highest TMP levels

374 (left) and the lowest TMP levels (right).

The proportion of urban/suburban land coverage was found to be higher in the catchment of the four

sites with the highest TMP concentrations compared to the four with the lowest TMP concentrations.

By contrast, the proportion of arable land coverage was higher across the catchment of sites with the lowest TMP concentrations compared to sites with the highest TMP concentrations.

380

\section{Prevalence of ARGs}

382

Only two SMX ARGs and three TMP ARGs were found at detectable levels in the metagenomes derived

from river sediment (Figure 7) and of these sul1 was detected at significantly higher levels in the

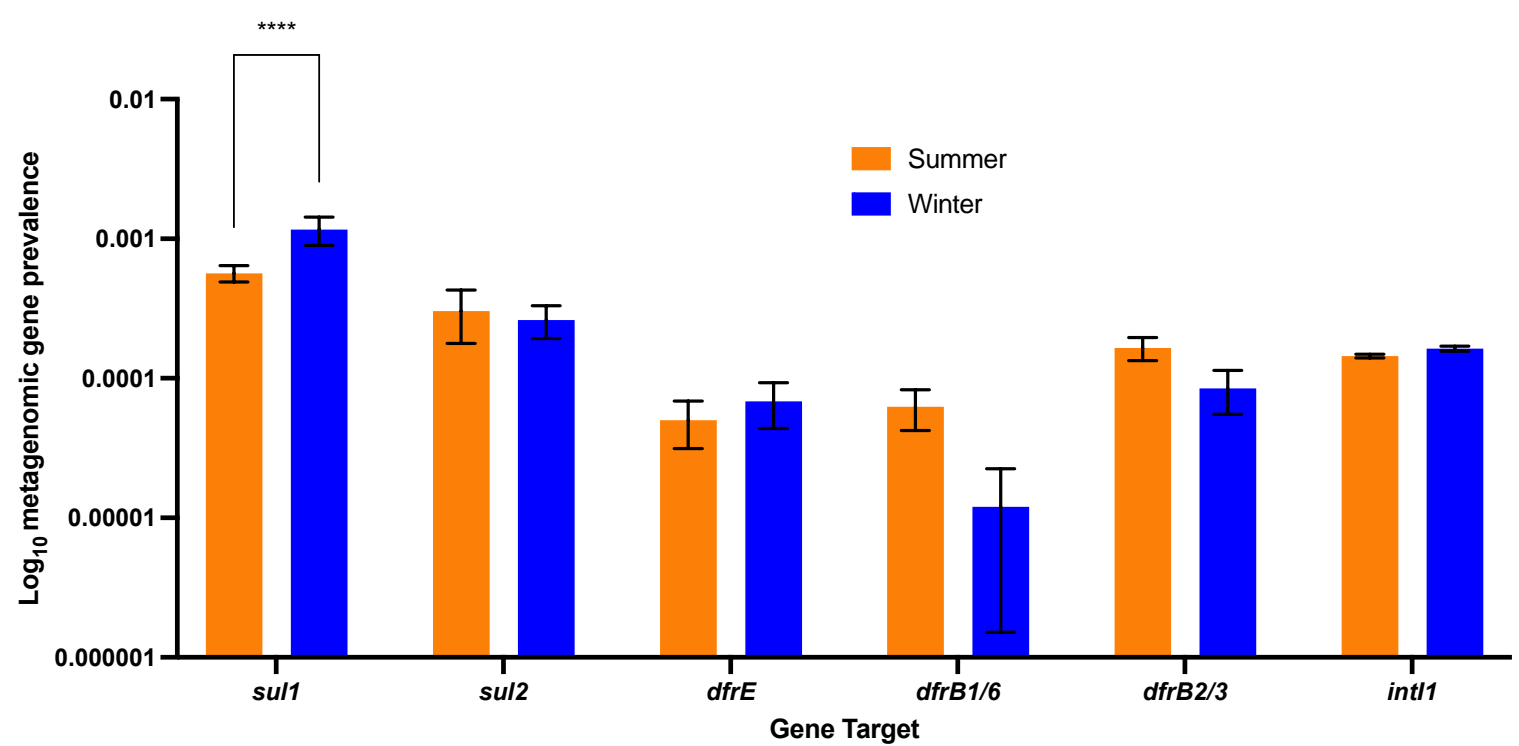

Figure 7- Prevalence of ARGs relevant to TMP/SMX resistance across 20 sites on the Thames 
398 The sul1 gene showed the highest overall prevalence compared to the four other ARGs relevant to and winter seasons (multiple t-tests).

401

The two ARGs relevant to SMX and the three ARGs relevant to TMP were then analysed in comparison

405

406

407

408

409

410
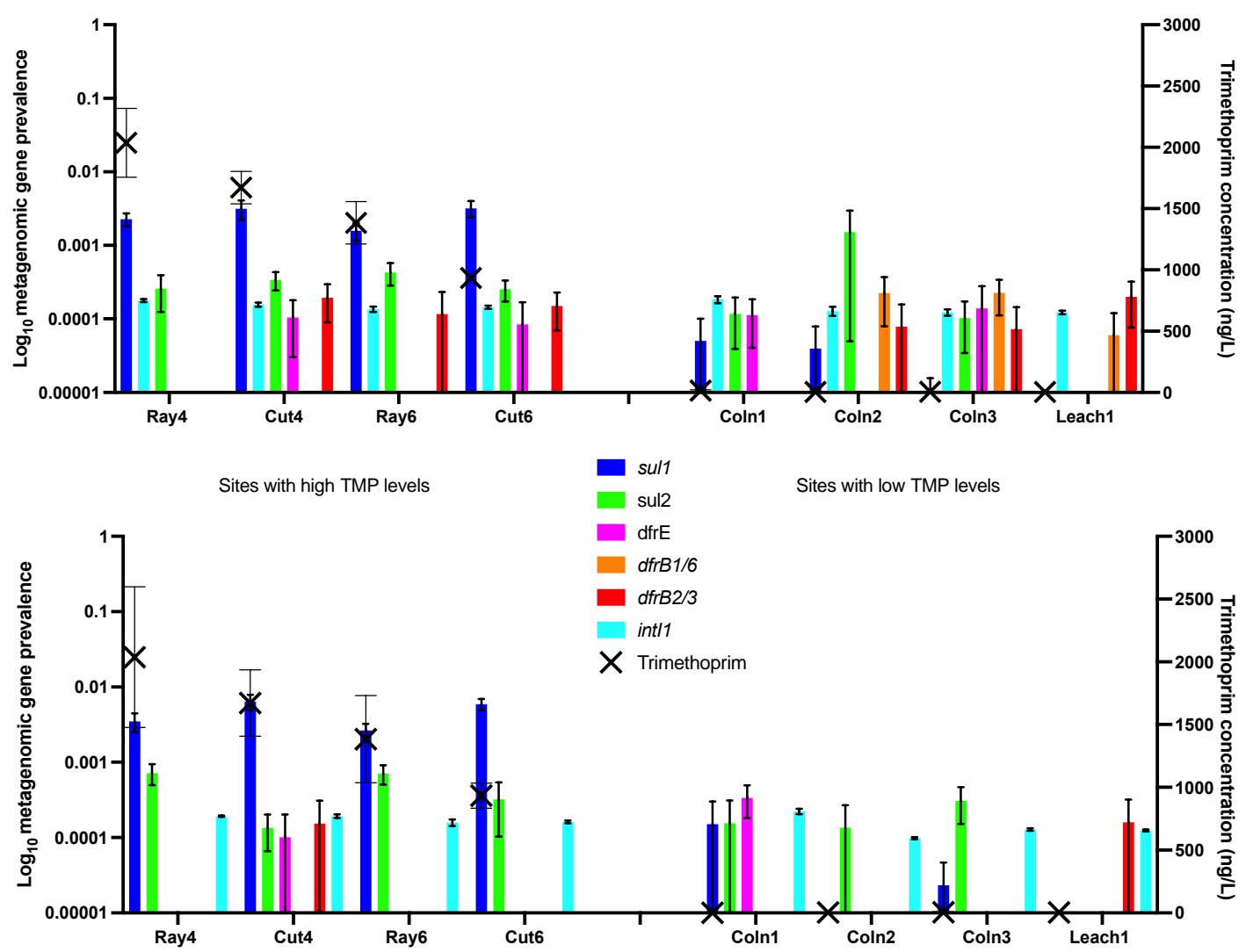

416 Figure 8- Prevalence of ARGs relevant to TMP/SMX and int/1 at sites with the four highest and four

417 lowest TMP levels in summer $(n=6)$ (above) compared to winter $(n=3)$ (SEM).

418 The prevalence of sul1 was higher at sites Ray4, Ray6 and Cut4 in winter compared to summer. At

419 these four sites, the prevalence of sul1 was higher than any of the prevalence of any other genes in

420 both winter and summer. Coln2 and Coln3 showed significantly higher prevalence's of $d f r B 1 / 6$ in 
higher in summer compared to winter (two-way ANOVA).

\section{Discussion}

Over the last two decades, the occurrence of antibiotics in water bodies and the potential for the

development of antimicrobial resistance (AMR) as a result has become an issue of concern (Khan et

al, 2013). Particularly in urban areas, waste-water treatment plants (WWTPs) are among the main

recipients of antibiotics, some of which will persist after treatment and can be released into nearby rivers (Rodriguez-Mozaz et al, 2020).

The levels of two clinically relevant antibiotics (trimethoprim (TMP) and sulfamethoxazole (SMX)) were analysed at river sites during this study. Results showed that nineteen of the twenty river sites analysed showed higher levels of TMP compared to SMX. TMP and SMX can be co-prescribed as cotrimoxazole, which might suggest that their levels identified in rivers might be similar. However, clinical antibiotic surveillance data shows that TMP is more commonly prescribed as a single dose antibiotic (Ashiru-Oredope et al, 2014). By contrast, veterinary surveillance data suggests that TMP is co-prescribed with 'sulfonamides' in high levels in agricultural settings (Bos et al, 2019). As a result, it is possible that TMP levels were higher than SMX levels at these sites because the two drugs are more often being used for different purposes and therefore more likely to be found at different river sites.

440 Another possible reason why TMP was significantly higher than SMX at certain sites could be the 441 differing biodegradation profiles that the drugs display in the environment (Thiebault, 2020). One 442 study used batch reactors containing wastewater matrices to show that the biodegradation rate of 443 SMX was significantly higher than TMP over a 21-day period (Pérez et al, 2005). Most WWTPs are 444 designed to extract nutrients and easily degradable carbon compounds. However, it has been shown 
TMP in rivers and streams (Metcalfe et al, 2010; Sengupta et al, 2014). The presence of antibiotics in

447 the treatment process can inhibit the biological activity of activated sludge, meaning that the 448 antibiotics themselves are not degraded effectively (Al-Riyami et al, 2018). As a result, it is possible that SMX is more readily degraded than TMP as part of the WWTP process and therefore was found in higher concentrations at certain sites.

452 As a result of the incapacity of conventional treatment systems to remove emerging contaminants such as antibiotics during treatment, studies have indicated that urban-associated river sites often have the highest concentrations of antibiotics (Chen et al, 2018; Lundborg et al, 2017). This would explain why TMP and SMX were both detected at river sites in this study, particularly as those sites with the highest TMP levels all had a high level of urban/suburban land coverage associated with them. The significant negative correlation between levels of TMP and the distance of a site from a

WWTP further suggests that the TMP being identified in rivers coming from WWTPs. Furthermore, in areas of high human population, it has been shown that excretion by humans contributes to most of

460 the pharmaceutical waste that ends up in domestic sewers and is eventually transported to WWTPs

461 (Tehrani and Gilbrade, 2018). This would explain the fact that the PE was significantly higher at the 462 four sites with the highest TMP concentrations compared to those with the lowest TMP concentrations.

During this study, four river sites (Cut4, Cut6, Ray4 and Ray6) were shown to have elevated levels of TMP. Despite showing significantly higher levels of TMP compared to all other sites, they did not show

467 a significantly higher prevalence of the ARGs that are known to confer resistance to TMP (Dfr genes). DfrB1/6 for example, was only detected at sites with the lowest TMP levels. This suggests that the concentrations of TMP at river sites are not directly selecting for resistance, which contrasts with previous reports which have shown that sub-Minimum inhibitory concentrations (MIC) of 
Yuen et al, 2018; Opatowski et al, 2010). Interestingly, sites with the highest levels of the SMX associated ARG sul1 did not show high levels of SMX but did show high levels of TMP. One possible explanation for why this happens is that TMP is indirectly selecting for sul1 by selecting for the presence of class 1 integrons (CL1s), as CL1s are known to carry the sul1 gene. CL1s which have been shown to confer resistance to several antibiotics, including SMX, TMP, amoxicillin (AMX), tetracycline (TCN) and erythromycin (ERY) (Langata et al, 2019; Ndi and Barton, 2011; Callejas et al, 2019). Our previous data showed no significant correlations between TCN and ERY concentrations with sul1 prevalence, but we do not have chemical data available relating to AMX (Holden et al, 2020). It is also possible that concentrations of $A M X$ are present at these river sites and they are also able to select for CL1s and therefore sul1. This effect has been noted in a previous study (Ironmonger et al, 2018). significantly between river sites or seasons like sul1 did, it seems unlikely that this is the case. Another possible explanation is that both TMP and sul1 are released to rivers following the waste-water treatment process at the same time, and therefore were both detected by coincidence. This would mean that the relationship between TMP and sul1 noted in this paper and our previous study is purely correlative (Holden et al, 2020).

Data from this study showed seasonal variation in the prevalence of individual ARGs and the 490 concentrations of TMP/SMX antibiotics at river sites. For example, the prevalence of sul1 over the 20 491 sites was significantly higher in winter compared to summer. Also, the concentration of TMP was 492 significantly higher in winter compared to summer for ten of the twenty sites analysed. Increased prescription/use of TMP in the population during the winter months could increase the concentrations

494 detected at river sites and potentially the prevalence of ARGs. A recent study indicated that prescription rates for antibiotics (including TMP) by General Practitioners (GPs) in the West Midlands 
497 increase in antibiotic consumption can increase the antibiotic concentration found in sewage, which

498 will eventually be treated by WWTPs (Pärnänen et al, 2019). If antibiotics are not successfully removed

499 during sewage treatment processes, then the higher concentrations of TMP shown in winter

500 compared to summer could be due to increased antibiotic usage/consumption. However, with regards

501 the chemical analysis of TMP and SMX, it must be acknowledged that the freshwater samples used

502 were collected over two summer seasons (summer 2015 and summer 2016) and only one winter

503 season (winter 2016). Also, the concentrations of chemicals determined at each site are only reflective

504 of the concentration of that chemical at one particular time, with no corrections made for the flow

505 rate of the individual river site or data on sewage spills from WWTPs. As a result, the chemical data

506 shown is potentially not reflective of the whole seasons analysed and the differences between TMP

507 concentrations in summer and winter is potentially more of a temporal effect as opposed to a seasonal

508 one.

509

510 One site in this study; Coln2 showed a showed significantly increased prevalence of sul2 in summer 511 despite having minimal concentrations of TMP and SMX, which contrasted with its low sul1 prevalence.

512 Sul2 is a sulfonamide resistant dihydropteroate synthase of gram-negative bacteria, generally found on

513 small plasmids, whereas sul1 is generally found linked to other resistance genes on CL1s (Antunes et al,

514 2005; Jia et al, 2017). According to the National Office of Animal Health (NOAH), there are two different

515 sulfonamide classes in addition to SMX that can be prescribed in combination with TMP to treat

516 infections in farm animals: sulfadiazine (SDZ) and sulfadoxine (SX) (NOAH, 2020). TMP-SDZ is a short-

517 acting bacteriostatic antibiotic that is typically applied to treat infections in horses (Ensink et al, 2003).

518 TMP-SX is a bacteriostatic antibiotic typically used to treat respiratory tract infections in cattle (Dunkley, 519 1994). Previous studies have noted increased abundance of the sul2 in agricultural samples containing 520 SDZ (Jechalke et al, 2012; Kopmann et al, 2012). As a result, is possible that the increased prevalence of 
bioRxiv preprint doi: https://doi.org/10.1101/2020.06.05.133348; this version posted May $21,2021$. The copyright holder for this preprint (which was not certified by peer review) is the author/funder. All rights reserved. No reuse allowed without permission.

sul2 shown at Coln2 in spite of the low SMX and TMP concentrations is driven by an agriculturally relevant sulfonamide such as SDZ, which was not targeted by the chemical analysis of this study. This is further emphasised by the fact that there was no relationship between sul2 and int/1 prevalence in this study, as this shows that sul2 genes are not emerging on CL1s alongside clinically relevant ARGs. However, it must be acknowledged that the available UK antibiotic surveillance data for veterinary applications only shows data for 'sulfonamides' as a general class, as opposed to distinguishing between individual drugs such as SMX and SDZ (Bos et al, 2019). As a result, it is difficult to determine the actual levels of SDZ that are being applied in agriculture. Also, despite the isolated high levels of sul2 at Coln2, this study showed that across all 20 sites on the Thames catchment, sul1 was significantly more prevalent than sul 2.

\section{Conclusions}

This study involved comparative analysis of large metagenomic, chemical and geospatial datasets to investigate the impact of antimicrobials such as trimethoprim (TMP) on the profile of antimicrobial resistance and the wider river microbiome. The following conclusions were drawn:

1) Nineteen of the twenty sites analysed showed higher levels of trimethoprim (TMP) than sulfamethoxazole (SMX), except for Thame7.

2) There was a significant negative correlation between the distance of river sites from waste-water treatment plants (WWTP) and the levels of TMP detected.

3) Of the twenty river sites analysed, four showed particularly high levels of TMP. For three of these four sites, TMP levels were significantly higher in winter compared to summer. 
4) $D f r E, D f r B 1 / 6, D f r B 2 / 3$ and int/1 prevalence at the four sites with the highest TMP levels were not significantly higher than those with the lowest TMP levels. $D f r E, D f r B 1 / 6, D f r B 2 / 3$ was significantly higher in summer compared to winter. int/1 prevalence showed no significant seasonal variation.

5) The four sites with high TMP levels showed significantly higher PE (population equivalence) levels than the four sites with the lowest TMP levels.

6) The land coverage of the four sites with the highest TMP levels were significantly more urban/suburban than the four sites with the lowest TMP levels. By contrast, the land coverage of the four sites with the lowest TMP levels was significantly more arable than those with the highest TMP levels.

558

559

\section{Future Work}

Our previous work has shown evidence of a significant positive correlation between TMP levels and the prevalence of sul1 at sites across the Thames catchment (Holden et al, 2020). Data from this study

7) sul1 prevalence at the four sites with the highest TMP levels were significantly higher than those with the lowest TMP levels. sul1 prevalence was also significantly higher in winter compared to summer.

8) sul2 prevalence at one of the sites with the lowest TMP levels (Coln2) was significantly higher than those with the highest TMP levels. sul2 prevalence at the Coln2 was also significantly higher in summer compared to winter. pinpointed the sites with the highest levels of TMP and the highest prevalence of sul1. 
bioRxiv preprint doi: https://doi.org/10.1101/2020.06.05.133348; this version posted May $21,2021$. The copyright holder for this preprint

(which was not certified by peer review) is the author/funder. All rights reserved. No reuse allowed without permission.

572 We have also shown that sites with the highest TMP concentrations and highest sul1 prevalence are

573 generally located closer to WWTPs than those with low TMP concentrations. Furthermore, sites with

574 the highest TMP concentrations have a higher PE, are more urban/suburban and that their TMP

575 concentration/sul1 prevalence is higher in winter compared to summer. Despite this, there is still no

576 previously explained mechanism as to why levels of TMP would select for sul1 directly.

577

578 definitive evidence of a causative impact of TMP concentrations on the prevalence of ARGs such as

sul1. Future work will aim to look at whether or not the concentrations of TMP and SMX recorded in

580 this study can have a significant causative impact on the prevalence of relevant ARGs.

581

582 References

583

584 1. Adelowo, O.O., Caucci, S., Banjo, O.A., Nnanna, O.C., Awotipe, E.O., Peters, F.B., Fagade,

585 O.E., and Berendonk, T.U. (2018) Extended Spectrum Beta-Lactamase (ESBL)-producing bacteria

586 isolated from hospital wastewaters, rivers and aquaculture sources in Nigeria. Environ Sci Pollut Res

$587 \quad$ Int 25: 2744-2755.

588

589 2. Alsaad, N., van Altena, R., Pranger, A.D., van Soolingen, D., de Lange, W.C., van der Werf,

590 T.S., Kosterink, J.G., and Alffenaar, J.W. (2013) Evaluation of co-trimoxazole in the treatment of

591 multidrug-resistant tuberculosis. Eur Respir J 42: 504-512.

592

593 3. Amos, G.C., Gozzard, E., Carter, C.E., Mead, A., Bowes, M.J., Hawkey, P.M., Zhang, L., Singer,

594 A.C., Gaze, W.H., and Wellington, E.M. (2015) Validated predictive modelling of the environmental

595 resistome. ISME J 9: 1467-1476. 
4. Amos, G.C.A., Ploumakis, S., Zhang, L., Hawkey, P.M., Gaze, W.H., and Wellington, E.M.H.

598 (2018) The widespread dissemination of integrons throughout bacterial communities in a riverine system. ISME J 12: 681-691.

600

601

5. Ashiru-Oredope, D., Hopkins, S., and Group, E.S.P.f.A.U.a.R.O. (2013) Antimicrobial stewardship: English Surveillance Programme for Antimicrobial Utilization and Resistance (ESPAUR).

J Antimicrob Chemother 68: 2421-2423.

604

605

6. Aslam, B., Wang, W., Arshad, M.I., Khurshid, M., Muzammil, S., Rasool, M.H., Nisar, M.A.,

606

Alvi, R.F., Aslam, M.A., Qamar, M.U., Salamat, M.K.F., and Baloch, Z. (2018) Antibiotic resistance: a rundown of a global crisis. Infect Drug Resist 11: 1645-1658.

608

7. Baharoglu, Z., and Mazel, D. (2014) SOS, the formidable strategy of bacteria against aggressions. FEMS Microbiol Rev 38: 1126-1145.

611

612

8. Baquero, F., Martínez, J.L., and Cantón, R. (2008) Antibiotics and antibiotic resistance in

613 water environments. Current Opinions in Biotechnology 19: 260-265

614

615

9. Bengtsson-Palme, J., Kristiansson, E., and Larsson, D.G.J. (2018) Environmental factors

616 influencing the development and spread of antibiotic resistance. FEMS Microbiol Rev 42.

617

618 10. CEH(2016) https://www.ceh.ac.uk/sites/default/files/LCM2015_Dataset_Documentation.pdf 619 Accessed April 28, 2020. 
622 11. Chen, Y., Xi, X., Xu, J., Xie, R., and Jiang, J. (2018) Distribution patterns of antibiotic residues

623 in an urban river catchment. Water and Environment Journal 33: 31-39.

624

625 12. Creating a River Thames fit for our future: an updated strategic and economic case for the

626 Thames Tideway Tunnel Department for Environment, Food and Rural Affairs

627 (DEFRA)2015 https://assets.publishing.service.gov.uk/government/uploads/system/uploads/attach

628 ment_data/file/471847/thames-tideway-tunnel-strategic-economic-case.pdf

629

630 13. Dan A, Yang, Y., Dai, Y.N., Chen, C.X., Wang, S.Y., and Tao, R. (2013) Removal and factors

631 influencing removal of sulfonamides and trimethoprim from domestic sewage in constructed

632 wetlands. Bioresour Technol 146: 363-370.

633

634 14. Davies, J., and Davies, D. (2010) Origins and evolution of antibiotic resistance. Microbiol Mol

Biol Rev 74: 417-433.

636

637 15. Di Cesare, A., Eckert, E.M., Rogora, M., and Corno, G. (2017) Rainfall increases the

638 abundance of antibiotic resistance genes within a riverine microbial community. Environ Pollut 226:

$639 \quad 473-478$.

640

641 16. Fouz, N., Pangesti, K.N.A., Yasir, M., Al-Malki, A.L., Azhar, E.I., Hill-Cawthorne, G.A., and Abd

642 El Ghany, M. (2020) The Contribution of Wastewater to the Transmission of Antimicrobial

643 Resistance in the Environment: Implications of Mass Gathering Settings. Trop Med Infect Dis 5. 
645 17. Frank, T., Gautier, V., Talarmin, A., Bercion, R., and Arlet, G. (2007) Characterization of

646 sulphonamide resistance genes and class 1 integron gene cassettes in Enterobacteriaceae, Central

647 African Republic (CAR). J Antimicrob Chemother 59: 742-745.

648

649 18. Hyatt, D., Chen, G.L., Locascio, P.F., Land, M.L., Larimer, F.W., and Hauser, L.J. (2010)

650 Prodigal: prokaryotic gene recognition and translation initiation site identification. BMC

651

Bioinformatics 11: 119.

652

653

19. Händel, N., Schuurmans, J.M., Brul, S., and ter Kuile, B.H. (2013) Compensation of the

metabolic costs of antibiotic resistance by physiological adaptation in Escherichia coli. Antimicrob

655

Agents Chemother 57: 3752-3762.

656

657 20. Händel, N., Schuurmans, J.M., Feng, Y., Brul, S., and ter Kuile, B.H. (2014) Interaction between mutations and regulation of gene expression during development of de novo antibiotic resistance. Antimicrob Agents Chemother 58: 4371-4379.

660

21. Holden, J., Raguideau, S., Zhang, L., Tipper, H.J, Delaney, J., Hill, G.L et al. (2020) How sewage

662 impacts antibiotic levels and bacterial resistance in the Thames catchment. To be released

663

664 22. Ironmonger, D., Edeghere, O., Verlander, N.Q., Gossain, S., Hopkins, S., Hilton, B., and 665 Hawkey, P.M. (2018) Effect of general practice characteristics and antibiotic prescribing on 666 Escherichia coli antibiotic non-susceptibility in the West Midlands region of England: a 4 year 667 ecological study. J Antimicrob Chemother 73: 787-794. 
23. Jia, B., Raphenya, A.R., Alcock, B., Waglechner, N., Guo, P., Tsang, K.K., Lago, B.A., Dave,

B.M., Pereira, S., Sharma, A.N., Doshi, S., Courtot, M., Lo, R., Williams, L.E., Frye, J.G., Elsayegh, T.,

Sardar, D., Westman, E.L., Pawlowski, A.C., Johnson, T.A., Brinkman, F.S., Wright, G.D., and

McArthur, A.G. (2017) CARD 2017: expansion and model-centric curation of the comprehensive

antibiotic resistance database. Nucleic Acids Res 45: D566-D573.

674

675

24. Kemnic T.R. Coleman M. (2019) Trimethoprim Sulfamethoxazole In: StatPearls [Internet].

Treasure Island (FL): StatPearls Publishing; https://www.ncbi.nIm.nih.gov/books/NBK513232/.

677

678

25. Khan, G.A., Berglund, B., Khan K.M., Lindgren P.E \& Fick, J. (2013) Occurrence and abundance

of antibiotics and resistance genes in rivers, canal and near drug formulation facilities--a study in

Pakistan. PLoS One 28;8(6):e62712.

681

682

26. Kiiru, J., Butaye, P., Goddeeris, B.M., and Kariuki, S. (2013) Analysis for prevalence and physical linkages amongst integrons, ISEcp1, ISCR1, Tn21 and Tn7 encountered in Escherichia coli strains from hospitalized and non-hospitalized patients in Kenya during a 19-year period (19922011). BMC Microbiol 13: 109.

686

687

27. Lee, K., Kim, D.W., Lee, D.H., Kim, Y.S., Bu, J.H., Cha, J.H., Thawng, C.N., Hwang, E.M., Seong,

H.J., Sul, W.J., Wellington, E.M.H., Quince, C., and Cha, C.J. (2020) Mobile resistome of human gut and pathogen drives anthropogenic bloom of antibiotic resistance. Microbiome 8: 2.

690

28. Li, B., and Webster, T.J. (2018) Bacteria antibiotic resistance: New challenges and

692 opportunities for implant-associated orthopedic infections. J Orthop Res 36: 22-32. 
29. Li, D., Liu, C.M., Luo, R., Sadakane, K., and Lam, T.W. (2015) MEGAHIT: an ultra-fast single-

695 node solution for large and complex metagenomics assembly via succinct de Bruijn graph.

696

Bioinformatics 31: 1674-1676.

697

698

30. Li, H., Handsaker, B., Wysoker, A., Fennell, T., Ruan, J., Homer, N., Marth, G., Abecasis, G.,

699 Durbin, R., and Subgroup, G.P.D.P. (2009) The Sequence Alignment/Map format and SAMtools.

700 Bioinformatics 25: 2078-2079.

701

702 31. Long, H., Miller, S.F., Strauss, C., Zhao, C., Cheng, L., Ye, Z., Griffin, K., Te, R., Lee, H., Chen,

703 C.C., and Lynch, M. (2016) Antibiotic treatment enhances the genome-wide mutation rate of target

704 cells. Proc Natl Acad Sci U S A 113: E2498-2505.

705

706

32. Lood, R., Ertürk, G., and Mattiasson, B. (2017) Revisiting Antibiotic Resistance Spreading in

Wastewater Treatment Plants - Bacteriophages as a Much-Neglected Potential Transmission

708

Vehicle. Front Microbiol 8: 2298.

709

710

33. Lu, S., Wang, J., Chitsaz, F., Derbyshire, M.K., Geer, R.C., Gonzales, N.R., Gwadz, M., Hurwitz,

711 D.I., Marchler, G.H., Song, J.S., Thanki, N., Yamashita, R.A., Yang, M., Zhang, D., Zheng, C., Lanczycki,

712 C.J., and Marchler-Bauer, A. (2020) CDD/SPARCLE: the conserved domain database in 2020. Nucleic

713 Acids Res 48: D265-D268.

714

715 34. Lundborg, C.S., and Tamhankar, A.J. (2017) Antibiotic residues in the environment of South

716 East Asia. BMJ 358: j2440. 
bioRxiv preprint doi: https://doi.org/10.1101/2020.06.05.133348; this version posted May $21,2021$. The copyright holder for this preprint (which was not certified by peer review) is the author/funder. All rights reserved. No reuse allowed without permission.

718

719

720

721

722

723

724

725

726

727

728

729

730

731

732

733

734

735

736

737

738

739

740

741

742

35. Martínez, J.L. (2012) Natural antibiotic resistance and contamination by antibiotic resistance determinants: the two ages in the evolution of resistance to antimicrobials. Front Microbiol 3: 1.

36. Masters, P.A., O'Bryan, T.A., Zurlo, J., Miller, D.Q., and Joshi, N. (2003) Trimethoprimsulfamethoxazole revisited. Arch Intern Med 163: 402-410.

37. McCarthy, M., Spillane, S., Walsh, S., and Kendon, M. (2016) The meteorology of the exceptional winter of 2015/2016 across the UK and Ireland. Weather 71: 305-313.

38. Metcalfe, C.D., Chu, S., Judt, C., Li, H., Oakes, K.D., Servos, M.R., and Andrews, D.M. (2010)

Antidepressants and their metabolites in municipal wastewater, and downstream exposure in an urban watershed. Environ Toxicol Chem 29: 79-89.

39. Morris, D.G., Flavin, R.W., (1994) A digital terrain model for hydrology. Proc 4th International Symposium on Spatial Data Handling. Sub-set of UK $50 \mathrm{~m}$ by $50 \mathrm{~m}$ hydrological digital terrain model grids. Wallingford, NERC, Institute of Hydrology 1: 250-262.

40. Munro, K., Martins, C.P.B., Loewenthal, M., Comber, S., Cowan, D.A., Pereira, L., and Barron, L.P. (2019) Evaluation of combined sewer overflow impacts on short-term pharmaceutical and illicit drug occurrence in a heavily urbanised tidal river catchment (London, UK). Sci Total Environ 657: 1099-1111.

41. Muziasari, W.I., Managaki, S., Pärnänen, K., Karkman, A., Lyra, C., Tamminen, M., Suzuki, S., and Virta, M. (2014) Sulphonamide and trimethoprim resistance genes persist in sediments at Baltic Sea aquaculture farms but are not detected in the surrounding environment. PLoS One 9: e92702. 
744 42. Na, G., Zhang, W., Zhou, S., Gao, H., Lu, Z., Wu, X., Li, R., Qiu, L., Cai, Y., and Yao, Z. (2014)

Sulfonamide antibiotics in the Northern Yellow Sea are related to resistant bacteria: implications for antibiotic resistance genes. Mar Pollut Bull 84: 70-75.

43. Nagulapally, S.R., Ahmad, A., Henry, A., Marchin, G.L., Zurek, L., and Bhandari, A. (2009)

Occurrence of ciprofloxacin-, trimethoprim-sulfamethoxazole-, and vancomycin-resistant bacteria in a municipal wastewater treatment plant. Water Environ Res 81: 82-90.

751

752 161: 319-328.

44. O'Neill J., The Review on Antimicrobial Resistance (2016). Tackling Drug-Resistant Infections Globally: Final Report and Recommendations. Available at: http://amrreview.org/sites/default/files/160518 Final\%20paper with\%20cover.pdf

45. Opatowski, L., Mandel, J., Varon, E., Boëlle, P.Y., Temime, L., and Guillemot, D. (2010)

Antibiotic dose impact on resistance selection in the community: a mathematical model of betalactams and Streptococcus pneumoniae dynamics. Antimicrob Agents Chemother 54: 2330-2337.

46. Ordnancesurveycouk (2016) https://www.ordnancesurvey.co.uk/documents/os-mastermapsites-layer-user-guide.pdf.

47. Pallares-Vega, R., Blaak, H., van der Plaats, R., de Roda Husman, A.M., Hernandez Leal, L., van Loosdrecht, M.C.M., Weissbrodt, D.G., and Schmitt, H. (2019) Determinants of presence and removal of antibiotic resistance genes during WWTP treatment: A cross-sectional study. Water Res 
48. Papot, C., Massol, F., Jollivet, D., and Tasiemski, A. (2017) Antagonistic evolution of an

antibiotic and its molecular chaperone: how to maintain a vital ectosymbiosis in a highly fluctuating habitat. Sci Rep 7: 1454.

49. Pazda, M., Kumirska, J., Stepnowski, P., and Mulkiewicz, E. (2019) Antibiotic resistance genes

50. Phuong Hoa, P.T., Nonaka, L., Hung Viet, P., and Suzuki, S. (2008) Detection of the sul1, sul2, and sul3 genes in sulfonamide-resistant bacteria from wastewater and shrimp ponds of north

Vietnam. Sci Total Environ 405: 377-384.

778

51. Pruden, A., Larsson, D.G., Amézquita, A., Collignon, P., Brandt, K.K., Graham, D.W., environment. Environ Health Perspect 121: 878-885.

783

52. Pruitt, K.D., Tatusova, T., and Maglott, D.R. (2005) NCBI Reference Sequence (RefSeq): a curated non-redundant sequence database of genomes, transcripts and proteins. Nucleic Acids Res 33: D501-504.

53. Pärnänen, K., Karkman, A., Hultman, J., Lyra, C., Bengtsson-Palme, J., Larsson, D.G.J., 
54. Pérez, S., Eichhorn, P., and Aga, D.S. (2005) Evaluating the biodegradability of

sulfamethazine, sulfamethoxazole, sulfathiazole, and trimethoprim at different stages of sewage

treatment. Environ Toxicol Chem 24: 1361-1367.

796

797

55. Quinlan, A.R., and Hall, I.M. (2010) BEDTools: a flexible suite of utilities for comparing

genomic features. Bioinformatics 26: 841-842.

799

800

56. Razavi, M., Marathe, N.P., Gillings, M.R., Flach, C.F., Kristiansson, E., and Joakim Larsson,

801

D.G. (2017) Discovery of the fourth mobile sulfonamide resistance gene. Microbiome 5: 160.

802

803 57. Rowland, C.S., Morton, R.D., Carrasco, L., McShane, G., O'Neil, A.W., Wood, C.M. (2017).

804 Land Cover Map 2015 (25m raster, GB). NERC Environmental Information Data

805 Centre. https://doi.org/10.5285/bb15e200-9349-403c-bda9-b430093807c7.

806

58. Sengupta, A., Lyons, J.M., Smith, D.J., Drewes, J.E., Snyder, S.A., Heil, A., and Maruya, K.A.

808 (2014) The occurrence and fate of chemicals of emerging concern in coastal urban rivers receiving

809 discharge of treated municipal wastewater effluent. Environ Toxicol Chem 33: 350-358.

810

811 59. Sewage Treatment in the UK

812 (2020) Assetspublishingservicegovuk https://assets.publishing.service.gov.uk/government/uploads/ system/uploads/attachment_data/file/69582/pb6655-uk-sewage-treatment-020424.pdf.

60. Singer, A.C., Shaw, H., Rhodes, V., and Hart, A. (2016) Review of Antimicrobial Resistance in

816 the Environment and Its Relevance to Environmental Regulators. Front Microbiol 7: 1728. 
818 61. Singer, A.C., Xu, Q., and Keller, V.D.J. (2019) Translating antibiotic prescribing into antibiotic

819 resistance in the environment: A hazard characterisation case study. PLoS One 14: e0221568.

820

821 62. Sköld, O. (2000) Sulfonamide resistance: mechanisms and trends. Drug Resist Updat 3: 155822160.

823

824 63. SOAF (2018) Waterorguk http://www.water.org.uk/wp-

content/uploads/2018/12/SOAF.pdf. Accessed May 7, 2020.

826

827

64. Stoodley, P., Wilson, S., Hall-Stoodley, L., Boyle, J.D., Lappin-Scott, H.M., and Costerton, J.W.

828 (2001) Growth and detachment of cell clusters from mature mixed-species biofilms. Appl Environ

Microbiol 67: 5608-5613.

830

831

65. Tehrani, A.H., and Gilbride, K.A. (2018) A closer look at the antibiotic-resistant bacterial

community found in urban wastewater treatment systems. Microbiologyopen 7: e00589.

833

834 66. Thiebault, T. (2020) Sulfamethoxazole/Trimethoprim ratio as a new marker in raw

835 wastewaters: A critical review. Sci Total Environ 715: 136916.

836

837 67. Thiebault, T., Fougère, L., Destandau, E., Réty, M., and Jacob, J. (2019) Impact of

838 meteorological and social events on human-excreted contaminant loads in raw wastewater: From

839 daily to weekly dynamics. Chemosphere 230: 107-116.

840

841 68. Tran, N.H., Hoang, L., Nghiem, L.D., Nguyen, N.M.H., Ngo, H.H., Guo, W., Trinh, Q.T., Mai,

842 N.H., Chen, H., Nguyen, D.D., Ta, T.T., and Gin, K.Y. (2019) Occurrence and risk assessment of 
846 69. Uyaguari-Díaz, M.I., Croxen, M.A., Luo, Z., Cronin, K.I., Chan, M., Baticados, W.N., Nesbitt,

847 M.J., Li, S., Miller, K.M., Dooley, D., Hsiao, W., Isaac-Renton, J.L., Tang, P., and Prystajecky, N. (2018)

848 Human Activity Determines the Presence of Integron-Associated and Antibiotic Resistance Genes in

849 Southwestern British Columbia. Front Microbiol 9: 852.

850

851 70. Vilchèze, C., and Jacobs, W.R. (2012) The combination of sulfamethoxazole, trimethoprim, 852 and isoniazid or rifampin is bactericidal and prevents the emergence of drug resistance in 853 Mycobacterium tuberculosis. Antimicrob Agents Chemother 56: 5142-5148.

71. Wellington, E.M., Boxall, A.B., Cross, P., Feil, E.J., Gaze, W.H., Hawkey, P.M., JohnsonRollings, A.S., Jones, D.L., Lee, N.M., Otten, W., Thomas, C.M., and Williams, A.P. (2013) The role of

857 the natural environment in the emergence of antibiotic resistance in gram-negative bacteria. Lancet Infect Dis 13: 155-165.

859

860 72. Wick, R.R., Schultz, M.B., Zobel, J., and Holt, K.E. (2015) Bandage: interactive visualization of 861 de novo genome assemblies. Bioinformatics 31: 3350-3352.

862

863 73. Zhang, X., Li, Y., Liu, B., Wang, J., Feng, C., Gao, M., and Wang, L. (2014) Prevalence of

864 veterinary antibiotics and antibiotic-resistant Escherichia coli in the surface water of a livestock production region in northern China. PLoS One 9: e111026. 
867 74. Östman, M., Lindberg, R.H., Fick, J., Björn, E., and Tysklind, M. (2017) Screening of biocides,

868 metals and antibiotics in Swedish sewage sludge and wastewater. Water Res 115: 318-328.

869

$87075 . \quad$ Šeputienè, V., Povilonis, J., Ružauskas, M., Pavilonis, A., and Sužiedèlienè, E. (2010)

871 Prevalence of trimethoprim resistance genes in Escherichia coli isolates of human and animal origin

872 in Lithuania. J Med Microbiol 59: 315-322. 